\title{
PENGARUH WARNA NAUNGAN PLASTIK DAN DOSIS PUPUK ORGANIK KOMPOS TERHADAP PERTUMBUHAN BAWANG MERAH (Allium ascalonicum L.)
}

\author{
(Influence Of Color Plastic Shade And Dosage of compost organic fertilizer \\ On The Growth Shallots (Allium ascalonicum L.))
}

\author{
Iskandar Umarie*, Wiwit Widarti, Insan Wijaya, Hudaini Hasbi \\ Fakutas Pertanian Universitas Muhammadiyah Jember \\ Jl. Karimata No. 49 Jember - Jawa Timur - Indonesia Phone \& Fax : (0331) 336728; \\ 337957 \\ *Email: iskandarumarie@unmuhjeber.ac.id
}

\begin{abstract}
The aim of the research was to study the effect of calors plastic shade and dosage organic fertilizer and the interaction on the growth analyze of Shallots. The experiment was conducted in experiment field of Agriculture Faculty, University Muhammadiyah of Jember. The experiment was arranged in Randomized Block Design consisted of $4 \times 3$ factorial treatments with three replications. The first factor were 3 levels of Transparent Plastic Shelter, i.e.: clear, blue, and red. The second factor were 4 levels of compost organic fertilizer application, i.e.: 15, 20, 25 and $30 \mathrm{t} / \mathrm{ha}$. The results showed a significant interaction between the color shade of plastic and a dose of organic fertilizer on the parameters of leaf area age 60 days after planting and leaf area index age 60 days after planting, treatment shade of blue with organic fertilizer 30 tons / ha showed the best effect on leaf area and treatment shade of blue with dosages of 25 tons / ha showed the best effect on leaf area index. Use of shade of blue give the best effect on leaf area age 60 hst and shade of red gives the best effect on the growth rate of plants. The treatment dose of organic fertilizer 25 tons / ha gives the best effect on leaf area index age of 60 days after planting, the rate of plant growth, and relative growth rate, and treatment with a dose of fertilizer 30ton / ha.
\end{abstract}

Key words: growth analyze, organic fertilizer application, transparent plastic shelter

\section{PENDAHULUAN}

Bawang

Merah

(Allium

ascalonicum L) telah lama diusahakan petani sebagai usaha pertanian yang komersial di Indonesia. Pengembangan bawang merah pada waktu yang akan datang sangat menjanjikan bila ditinjau dari segi permintaan yang terus meningkat sejalan dengan bertambah jumlah (Widodo, dkk., 2011 ). Bertambahnya kebutuhan dan permintaan bawang merah yang meningkat setiap tahunnya, belum diikuti oleh peningkatan produksimenjadikan Indonesia masih mengimport bawang merah untuk memenuhi kebutuhan dalam negeri (Elizabet, dkk., 2013). Penyebab utama rendahnya produksi ditingkat petani adalah keterbatasan dalam hal teknologi produksi 
bawang merah seperti bervariasinya kesuburan dan macam tanah, pemupukan, pengendalian hama dan penyakit, gulma serta pengelolaan pascapanennya. Terjadinya fluktuasi hasil akibat dari fluktuasi faktor eksternal (lingkungan) yang terkait dengan tata cara stabilitas penampilan tanaman, untuk itu pengembangan bawang merah kedepan lebih diarahkan pada keserasian faktor fisik lingkungan secara optimal (Suriani, 2012). Salah satu faktor kesesuaian faktor fisik lingkungan yang membatasi produksi tanaman bawang merah adalah kesuburan tanah dan penyinaran matahari.

Perkembangan dan pertumbuhan tanaman sangat dipengaruhi oleh ketersediaan unsur hara dan pemberian pupuk di dalam tanah. Pertumbuhan tanaman dibatasi oleh kandungan unsur hara dalam keadaan minimum, dengan demikian pertumbuhan tanaman dikendalikan oleh status hara terkecil. Keseimbangan unsur hara yang di perlukan oleh tanaman untuk mecapai pertumbuhan optimal mutlak dilakukan, artinya tidak boleh ada satupun unsur hara yang menjadi faktor minimum (pembatas) (Pahan, 2008). Perbaikan teknologi budidaya melalui pemberian pupuk organik merupakan satu usaha untuk meningkatkan produksi bawang. Elizabet, $d k k$. (2013) menjelaskan bahwa pemberian pupuk hayati (organic) memiliki keutamaan diantaranya memulihkan struktur dan tektur tanah serta meminimalkan efek residu, sehingga tidak menimbulkan dampak yang tidak baik terhadap lingkungan. Hasil penelitian Nadirin (2000), menyatakan bahwa pemberian pupuk kandang sapi sebanyak 7,5 ton $\mathrm{Ha}^{-1}$ mampu meningkatkan produksi sawi sebesar 3,2 $\mathrm{kg}$ per $\mathrm{m}^{-2}$. Hasil riset yang dilakukan Muku (2002) bahwa pemberian pupuk organik sapi 15 ton $\mathrm{Ha}^{-1}$ menghasilkan umbi bawang merah sebanyak 15,3 ton/ ha.

Selain penggunaan pupuk organik, upaya untuk meningkatkan produksi bawang merah yaitu dengan melakukan rekayasa pencahayaan matahari, melalui pemberian naungan plastik transparan. Usaha mendesain mikroklimat untuk mencapai pertumbuhan tanaman yang optimal merupakan ciri pertanian modern (Muamar, dan Maiyana, 2014). Sinar Surya menjadi faktor penting pada proses fotosintesis dan penentu laju pertumbuhan tanaman (LPT) sehingga lama penyinaran, kualitasnya dan intensitas sangat berpengaruh terhadap proses fotosintesis (Sumarni dan Rosliani, 2010). Variasi respon pertumbuhan dan produksi tanaman terhadap naungan dipengaruhi oleh sifatsifat fisiologi fotosintetik tanaman tersebut yang dapat dijadikan sebagai penanda toleransi terhadap cekaman naungan. Kemampuan toleransi tanaman yang beradaptasi pada intensitas cahaya rendah dengan tanaman yang peka erat kaitannya dengan sifat-sifat fisiologi fotosintetik tanaman tersebut (Pradesta, $d k k, 2017$ ).

Penelitian ini bertujuan untuk mendapatkan dosis pupuk organik dan naungan plastik yang terbaik untuk produksi umbi bawang merah melalui analisis tumbuh. Dari hasil penelitian ini diharapkan dapat memberikan informasi yang berguna untuk peningkatan produksi bawang merah.

\section{BAHAN DAN METODE}

Penelitian dilaksanakan di kebun percobaan Fakultas Pertanian Universitas Muhammadiyah Jember. Mulai pada tanggal 28 Maret 2018 sampai 30 juni 2018. Rancangan percobaan yang digunakan 
adalah Rancangan Acak Kelompok (RAK) faktorial, dengan 3 kali ulangan. Faktor pertama adalah warna naungan plastik transparan, dengan taraf: W1: Plastik transparan warna bening, W2: Plastik transparan warna biru, dan W3: Plastik transparan warna Merah. Naungan dipasang setelah bawang merah ditanam, cara pemasangannya disetiap pinggir bedengan diberi bambu melintang dan diikat dengan menggunakan tali agar naungan tidak terbang terbawa angin. kedua adalah Pupuk organik kompos dengan taraf : N1 $=15$ ton pupuk organik/ha, N2: 20 ton organik/ha, N3: 25 ton pupuk organik/ha, dan N4: 30 ton pupuk organik/ha. Pemberian pupuk organik kotoran sapi dilakukan pada saat 14 hari sebelum penanaman dengan cara menebarkan secara merata di lahan pecobaan. Pupuk organik kompos yang digunakan dalam penelitian ini berasal dari toko pertanian dengan kandungan $\mathrm{N}$-total $(\%)=1,07, \mathrm{P}_{2} \mathrm{O}_{5}$ $(\%)=0,74, \mathrm{~K}_{2} \mathrm{O}(\%)=2,12$, C-Organik $(\%)$ $=11,78$, dan $\mathrm{C} / \mathrm{N}$ Rasio $=11,01$

Adapun Parameter Pengamatan meliputi: 1) Luas daun, 2). Indeks luas daun tanaman, 3). Laju asimilasi bersih (neto), 4). Laju pertumbuhan relative, 5). Laju pertumbuhan tanaman, 6). Indeks panen. Analisis pertumbuhan tanaman berasal dari data berat kering tanaman dan luas daun tanaman. Data tersebut di dapat dari tanaman contoh yang dikorban, diambil di luar petak contoh. Laju asimilasi bersih (LAB), indeks luas daun (ILD) dan laju pertumbuhan tanaman (LPT) di peroleh dari pengamatan biomasa tanaman dan luas daun. Data komponen pertumbuhan tanaman, diolah dengan analisis varian pada taraf nyata 5 $\%$. Jika ada perbedaan yang nyata dilanjutkan uji DMRT pada taraf $5 \%$.

\section{HASIL DAN PEMBAHASAN \\ Luas Daun Tanaman}

Pengukuran luas daun tanaman merupakan salah satu pengamatan yang cukup penting dalam penelitian fisiologi dan agronomi. Hasil pengukuran tersebut dapat digunakan untuk menentukan indeks luas daun, laju asimilasi netto, efisiensi fotosintesis, dan potensi fotosintesis daun (Soejono, 2003). Luas daun yang tinggi pada perlakuan $\mathrm{N} 4$ berbeda nyata dengan perlakuan $\mathrm{N} 1, \mathrm{~N} 2$, dan $\mathrm{N} 3$ pada umur 30 hst, dan tingginya luas daun pada pada perlakuan W2 (plastik warna biru) dibandingkan dengan W1 (plastik bening) dan W3 (plastik merah), hasil di atas selaras dengan tingginya luas daun pada kombinasi perlakuan W2N4 (naungan wana biru dan pupuk organik 30 ton) (Tabel 1). Hal ini diduga karena perlakuan N4 (30 ton/ha pupuk organik) telah memberikan kecukupan unsur hara untuk pertumbuhan tanaman. Elizabet, $d k k$. (2013), menyatakan penambahan tinggi tanaman dan pembentukan daun-daun baru, karena dirangsang oleh tercukupinya kebutuhan tanaman terhadap unsur-unsur pertumbuhan. Bertambahnya jumlah daun baru pada tanaman menyebabkan luas daun per individu mengecil, tatapi total luas daun yang dihasilkan per tanaman meningkat. Penyerapan dan perubahan energi cahaya dalam pembentukan biji dan hasil panen sangat ditentukan oleh daun tanaman itu sendiri, karena daun tanaman merupakan tempat biologis fotosintetis, oleh sebab itu bertambahnya luas daun, berarti penyerapan cahaya oleh daun mengalami meningkat juga. Buhaira (2007) menjelaskan bahwa ruang tumbuh yang cukup diperlukan oleh tanaman untuk memaksimalkan penyerapan 
faktor pertumbuhannya, misalnya cahaya matahari, unsur hara, dan air.

Sedangkan tingginya luas daun pada perlakuan W2 (plastik warna biru) dibandingkan dengan W1 (plastik bening) dan W3 (plastik merah) (Tabel 1), diduga karena plastik biru (W3), lebih banyak menyalurkan warna cahaya berwarna biru, yang berkaitan dengan proses fotosintesis, sehingga dengan lebih banyaknya cahaya biru yang disalurkan untuk proses fotosintesis, maka terbentuknya organ, seperti daun, batang dan akar tanaman lebih baik. Sulistyaningsih, dkk., (2005), menyatakan perbedaan warna plastik yang digunakan akan berpengaruh pada panjang gelombang yang diterima. Fotosintesis dan reaksi fotokimia lainnya sangat tergantung pada jumlah foton atau kuanta yang diserap bukan pada energi total cahayanya (Salisbury dan Ross,1995). Widodo dan Purwanto (1985), menyatakan foton yang mempunyai efek penting dalam fotosintesis adalah foton spektrum merah dan foton spektrum biru. lebih lanjut Widodo dan Purwanto (1985), menyatakan bahwa panjang gelombang antara 400-510 $\mathrm{m \mu}$ (biru) klorofil banyak mengabsorbsi cahaya, pada gelombang ini proses fotosintesis lebih efektif.

\section{Indek Luas Daun}

Hasil biji maupun berat kering dari akar, dan juga hasil tanaman (Capriyati, suatu tanaman sangan berkaitan erat dengan $d k k$.,2014). Tingginya Laju Pertumbuhan Indeks luas daun tanaman (Chang, 1968). Relatif pada perlakuan N3 (25 ton Indek Luas Daun berada dalam keadaan organik/ha), yang berbedanya nyata dengan optimum akan tercapainya hasil biji N1, N2, dan N4 (Tabel 2), serta tingginya maksimum. Beets, 1982 dan Bilman, 2001, Laju Pertumbuhan Tanaman (LPT) pada menyatakan kecepatan fotosintesis mencapai naungan Biru (W2), yang berbeda nyata kondisi maksimum menandakan indek luas dengan naungan yang lainnya (W1 dan W3) daun tanaman mencapai kondisi optimum. (Tabel 2), diduga pada perlakuan N3 tersebut Diperolehnya Indek Luas Daun (ILD) yang sudah mencukupi kebutuhan unsur tanaman tetinggi pada perlakuan N3 (25 ton/ha) dan bawang merah, dan W2 (naungan Biru) lebih 
banyak menyalurkan cahaya yang dibutuhkan tanaman dalam proses fotosintesisnya, sehingga memacu tanaman bawang merah menyerap unsur hara, air dan cahaya matahari secara optimum.

Dalam usaha mengoptimalkan penyerapan cahaya matahari tanaman menunjukkan pertumbuhan memanjang agar memperoleh cahaya untuk memenuhi kebutuhan tanaman berfotosintesis (Bilman, 2001). Paham, 2008, untuk mencapai pertumbuhan optimal, tidak boleh ada satu unsur hara pun yang menjadi faktor pembatas, untuk itu seluruh unsur hara harus dalam keadaan seimbang. Lebih lanjut Greulach dan Adams (1962) menyatakan bahwa faktor klimatik yang mempengaruhi pertumbuhan tanaman diantaranya adalah temperatur, cahaya, kelembaban udara, komposisi gas di atmosfir, pergerakan udara, tekanan udara, dan presipitasi. Lingkungan fisik mempengaruhi pertumbuhan tanaman dalam tiga cara: mempengaruhi laju pertumbuhan dan pola perkembangan, juga menentukan bagaimana tanaman menurunkan sifat potensial tertentu untuk dapat bertahan dan tumbuh, sehingga mempengaruhi distribusi geografi tanaman tersebut.

\section{Laju Pertumbuhan Relatif}

Laju Pertumbuhan Relatif adalah akumulasi biomasa tanaman dalam suatu rentang waktu tertentu, hal ini juga erat hubungannya dengan berat awal tanaman. Persamaan kuantitatif untuk Laju Pertumbuhan Relatif di asumsikan dengan bertambanya biomassa tanaman pada waktu tertentu, biasanya tidak stabil namun tergantung pada berat awal tanaman (Sitompul dan Guritno, 1995). Tinggi Laju Pertumbuhan Relatif pada perlakuan N3 (25 ton/ha), berbeda secara signifikan dengan perlakuan lainnya (N1, N2, dan N4) (Tabel
2), diduga bahwa pada perlakuan tersebut kebutuhan akan unsur hara untuk pertumbuhan tanaman bawang merah telah tercukupi, dengan tercukupi unsur hara tanaman, dan cahaya matahari terpenuhi, proses metabolisme yang terjadi di dalam tanaman dapat berjalan optimum. Greulach dan Adams (1962) menjelaskan bahwa cahaya mempengaruhi tanaman pada fotosintesis, sintesis klorofil, fototropisme, dan pembukaan stomata. Fotosintesis yang dipengaruhi oleh kehadiran cahaya berpengaruh terhadap produksi dari bahan makanan untuk tanaman tersebut. Poorter dan Garnier (2007) menyatakan bahwa laju pertumbuhan relatif berubah secara kontinyu dengan ontogeni. Selama perkecambahan terdapat transisi bertahap dari pertumbuhan yang bergantung pada cadangan makanan pada biji menjadi autrotop lengkap. Ketika tanaman menjadi semakin tua dan besar, daun-daun bagian atas mulai menutupi daun bagian bawah. Kemudian tanaman yang telah dewasa akan mengalokasikan hasil fotosintesis kepada akar dan batang. Konsekuensi atas mekanisme tersebut adalah laju pertumbuhan relatif yang meningkat bersamaan dengan ukuran tanaman dan waktu.

\section{Laju Asimimilasi Bersih}

Laju asimilasi bersih adalah parameter efisiensi proses fotosintesis di daun dalam memanfaatkan radiasi matahari dan unsur hara. Peningkatan jumlah dan luas daun berarti semakin banyak penyerapan radiasi matahari. Hal ini berakibat pada proses fotosintesis, sehingga semakin banyak energi yang dihasilkan untuk pertumbuhan tanaman (Capriyati, 2014). Walaupun tidak berbeda nyata antara perlakuan pemupukan organik $(\mathrm{N})$, warna 
naungan (W), dan interkasi keduanya, namun perlakuan N3 (25 organik/ha), naungan bening (W1), dan interaksi pupuk organik 30 ton/ha dengan naungan merah (W3N4) menunjukkan kecendrungan Laju Asimilasi Bersih lebih tinggi dibandingkan dengan perlakukan lainnya (Gambar 1). Penyebab tidak terjadi perbedaan yang nyata antar perlakuan tersebut di duga karena sebagian besar daun sudah saling ternaungi, sehingga mempengaruhi berat kering dan luas daun tanaman. Berdasarkan perhitungan laju asimilasi bersih, komponen yang mempengaruhi besar kecilnya nilai laju asimilasi bersih ini adalah luas daun dan berat kering tanaman. Pada tanaman ternaungi, daun tanaman menjadi semakin lebar dan tipis, hal ini akan mengurangi penerimaan cahaya oleh daun yang letaknya dibawah tajuk. Menurut Gardner $d k k$. (1991) makin banyak daun yang terlindung menyebabkan penurunan laju asimilasi bersih sepanjang musim pertumbuhan. Jufri (2006) menyatakan bahwa kekurangan cahaya dapat menurunkan laju fotosintesis dan akumulasi karbohidrat yang berakibat pada terganggunya proses metabolisme dan produksi tanaman. Naungan juga menyebabkan cahaya yang digunakan untuk proses fotosintesis terhalang. Tanaman yang ternaungi jumlah cahaya yang masuk akan berkurang, hal ini mengakibatkan proses fotosintesis tidak dapat berjalan optimal sehingga pembentukan organ tanaman juga terhambat seperti daun dan stolon (Noviyanti, $d k k ., 2014$ ).

\section{Indek Panen Tanaman}

Indeks panen merupakan rasio penyebaran hasil asimilasi antara bagian bernilai ekonomi dan total bagian tanaman (Sulistyaningsih, dkk., 2005). Perlakuan naungan plastik dan pemupukan organik tidak berpengaruh tarhadap nilai indek panen tanaman bawang merah. Walaupun tidak ada perbedaan yang nyata antara perlakuan pemupukan organik $(\mathrm{N})$, warna naungan (W), dan interkasi keduanya pada indek panen, namun perlakuan N4 (30 organik/ha), naungan Merah (W3), dan interaksi pupuk organik 30 ton/ha dengan naungan bening (W1N4) menunjukkan kecendrungan Indek Penen lebih tinggi dibandingkan dengan perlakukan lainnya (Gambar 2).

Kapasitas tanaman untuk menambah bahan kering pada periode tertentu dari setiap bahan kering yang dihasilkan merupakan aktualisasi dari laju pertumbuhan nisbi tanaman (Kastono, 2005), dengan demikian untuk menghasilkan bahan baru tanaman tidak hanya daun yang berperan sebagai fotosintat, tetapi juga keseluruhan organ tanaman bekerjasama untuk menghasilkan fotosintat (Junita dkk., 2002 dan Anggraini, $d k k$., 2013). Indek panen yang non signifikan pada interaksi perlakuan penggunaan naungan dan pupuk organik, serta penggunaan warna naungan yang berbeda menghasilkan biomasa yang juga non signifikan pada akhirnya akan menghasilkan laju pertumbuah nisbi yang juga non signifikan, inilah yang diduga menjadi penyebab mengapa indek panen pada tanaman bawang merah non signifikan. Asimilat yang terbentuk dari proses fotosintesis akan distribusikan ke berbagai bagian tubuh tanaman. Penimbunan asimilat pada organ tanaman tersebut digunakan untuk proses pertumbuhan dan perkembangan tanaman. persaingan antar organ generative dan vegetatif dapat terjadi, apabila tanaman tidak mampu membentuk asimilat yang cukup untuk pertumbuahan dan perkembangan tanaman (Gardner, dkk., 1991 dan Beadle, 1993). 


\section{KESIMPULAN}

Terdapat interaksi yang nyata antara warna naungan plastik dan dosis pupuk organik kompos pada parameter luas daun daun umur 60 hst dan indek luas daun umur 60 hst, perlakuan naungan warna biru dengan pupuk organik 30 ton/ha menunjukkan pengaruh terbaik pada luas daun dan perlakuan naungan warna biru dengan dosis pupuk 25 ton/ha menunjukkan pengaruh terbaik pada indek luas daun.

Penggunaan naungan warna biru memberikan pengaruh terbaik pada luas daun umur 60 hst dan naungan warna merah memberikan pengaruh terbaik pada laju pertumbuhan tanaman.

Perlakuan dosis pupuk organik 25 ton/ha memberikan pengaruh terbaik pada indek luas daun umur 60 hst, laju pertumbuhan tanaman, dan laju pertumbuhan relatif, dan perlakuan pupuk dengan dosis 30ton/ha, menunjukkan pengaruh terbaik pada luas daun umur 60 hst dan indek luas daun umur 30 hst.

\section{UCAPAN TERIMAH KASIH}

Direktorat Riset dan Pengabdian Masyarakat, Direktorat Jenderal Penguatan Riset dan Pengembangan, Kemeterian Riset, teknolohi, dan Pendidikan Tinggi, yang membiayai penelitian ini sesuai dengan Kontrak Penelitian Nomor: 025/SP2H/LT/K7/KM/2018

\section{DAFTAR PUSTAKA}

Anggraini, Fita, Agus Suryanto, dan Nurul Aini. 2013. Sistem Tanam Dan Umur Bibit Pada Tanaman Padi Sawah (Oryza sativa L.) Varietas Inpari 13. Jurnal Produksi Tanaman. 1(2) : 50-61

Beadle, C. L. 1993. Growth analysis, p. 3645. In D.O. Hall, J.M.O. Scurlock, H.R. Bohlar-Nordenkampf, R.C.
Leegood, and S.P. Long (Eds.). Photosintesis and Production In A Changing Environment. Chapman \& Hall. London.

Beets, W. C., 1982. Multiple Cropping and Farming Gower Publishing Company Li- mited, Gower House, Croft Road, Aldershot, Hampshire, England. 156 p.

Bilman, WS. 2001. Analisis Pertumbuhan Tanaman Jagung Manis (Zea mays saccharata), Pergeseran Komposisi Gulma Pada Beberapa Jarak Tanam. Jurnal Ilmu-Ilmu Pertanian Indonesia. 3 (1) : . 25-30

Buhaira. 2007. Respons kacang tanah (Arachis hypogaea L.) dan jagung (Zea mays L.) terhadap beberapa pengaturan tanam jagung pada sistem tanam tumpangsari. Jurnal Agronomi 11: 4145

Capriyati, Riani, Tohari, dan Dody Kastono. 2014. Pengaruh Jarak Tanam dalam Tumpangsari Sorgum Manis (Sorghum bicolor L. Moench) dan Dua Habitus Wijen (Sesamum indicum L.) Terhadap Pertumbuhan dan Hasil. Vegetalika. 3 (3) : $49-62$

Chang, T.H., 1968. Climate AND Agriculture an Ecological Survey , Aldin Publshing, Company, Chicago. 296P..

Elizabet, Devi Budidaya, Nudji Santosa, dan Ninik Herlina. 2013. Pengaruh Pemberian Berbagai Komposisi Bahan Organik pada Pertumbuhan dan Hasil Tanaman Bawang Merah (Allium ascalonicum L.). Jurnal Produksi Tanaman. 1 (3) : 92-109

Gardner, F.P., R.B. Pearce, and R.L. Mitchell. 1991. Physiology of crop plants. Terjemahan: Fisiologi Tanaman Budidaya. Penerjemah: Herawati Susilo. Pendamping: 
Subiyanto. Universitas Indonesia Press, Jakarta

Greulach, V.A. and J.E. Adams. 1962. Plants an Introduction to Modern Botany. New York. John Wiley \& Sons. 636p.

Jufri, A. 2006. Mekanisme Adaptasi Kedelai (Glycine $\max (\mathrm{L})$ Merrill) terhadap Cekaman Intensitas Cahaya Rendah. Disertasi. Sekolah Pascasarjana Institut Pertanian. Bogor. 103hal.

Junita, F., S. Muhartini dan D. Kastono. 2002. Pengaruh Frekuensi Penyiraman dan Takaran Pupuk Kandang terhadap Pertumbuhan dan Hasil Pakchoi. Ilmu Pertanian. IX (1) : $37-45$

Kastono, D., H. Sawitri, dan Siswandono. 2005. Pengaruh nomor ruas setek dan dosis pupuk urea terhadap pertumbuhan dan hasil kumis kucing. Jurnal Ilmu Pertanian 12(1):56 - 64 .

Muamar, M. Rezeki, dan Maiyana. 2014. Pengaruh Penggunaan Sungkup Plastik Berwarna Terhadap Pertumbuhan Tanaman Sawi (Brassica rapa). JESBIO . III (5) : 1421

Muku, M.O. 2002. Pengaruh Jarak Tanam dalam Barisan dan Macam Pupuk Organik terhadap Pertumbuhan dan Hasil Tanaman Bawang Merah (Alium asca/onicum.L) di Lahan Kering. Pasca Sarjana, Universitas Udayana, Denpasar. Tesis. Tidak Dipulikasikan

Nadlirin. 2000. Pemberian Bahan Organik dan Pupuk Majemuk NPK untuk Meningkatkan Produksi dan Kualitas Sawi (Brassica juncea L.) pada Tanah Inceptisol Renon. Jurusan Ilmu Tanah. Fakultas Pertanian,
Universitas Udayana. Denpasar. Skripsi. Tidak Dipublikasikan

Noviyanti, Rine, Yuliani, Evie Ratnasari, dan Hasim Ashari. 2014. Pengaruh Pemberian Naungan terhadap Pertumbuhan Vegetatif Tanaman Stroberi Varietas Dorit dan Varietas Lokal Berastagi. LenteraBio. 3 (3): 242-247

Pahan, I. 2008. Panduan Lengkap Kelapa Sawit, Manajemen Agribisnis dari Hulu hingga Hilir. Jakarta : Penebar Swadaya.

Poorter, H. and E. Garnier. 2007. Ecological significance of inherent in relative growth rate and its components. In Functional Plant Ecology. F.I. Pugnaire and F. Valladare (Eds.). p67-100. New York. CRC Press. 724p.

Pradesta, Adisti Zahrotul, Koesriharti dan Tatik Wardiyati. 2017. Pengaruh Pemberian Sungkup Dan Komposisi Media Tanam Terhadap Pertumbuhan Setek Tanaman Nilam (Pogostemon cablin Benth.). Jurnal Produksi Tanaman: 5 (5) : 828-836

Salisbury, F.B. \& C.W. Ross. 1995. Plant Physiology. 4th Ed. Wadsworth Publishing Company Bellmount, California. 681 hal

Sitompul, S. M. dan Bambang Guritno., 1995. Analisis Pertumbuhan Tanaman. Gajah Mada University

Soejono, A.T. 2003. Pengaruh Jenis Dan Saat Tanam Tanaman Palawija Dalam Tumpangsari Tebu Lahan Kering Terhadap Pertumbuhan Dan Hasil Tanaman. Ilmu Pertanian. 10 (2) : 2634 
Sulistyaningsih, E., Kurniasih B., dan Kurniasih E. 2005. Pertumbuhan dan Hasil Caisin pada Berbagai Warna Sungkup Plastik. J. Ilmu Pertanian.12(1) : 65-76.

Sumarni, N. dan R. Rosliani. 2010. Pengaruh Naungan Plastik Transparan, Kerapatan Tanaman, dan Dosis N terhadap Produksi Umbi Bibit Asal Biji Bawang Merah. J. Hort. 20 (1) : 52-59

Widodo dan Purwanto. 1985. Dasar-Dasar Fisiologi Tumbuhan. Proyek
Peningkatan dan Pengebangan Perguruan Tinggi. Universitas Bengkulu. Bengkulu. 112 hal

Widodo, Winarso Drajat, Roedhy Poerwanto dan Nani Sumarni. 2011. Teknologi True Shallot Seed (Tss) Sebagai Bahan Tanam Untuk Meningkatkan Produktivitas Bawang Merah. Hasil Penel. Ristek 2011. Balitsa, Puslitbanghorti. Badan Litbang Pertanian. Kementrian Pertanian.

Tabel 1. Pengaruh pupuk organik, naungan plastik, dan interaksi pupuk organik dengan naungan terhadap luas daun, dan indek luas daun pada tanaman bawang merah

\begin{tabular}{|c|c|c|c|c|}
\hline \multirow[t]{2}{*}{ Perlakuan } & \multicolumn{2}{|c|}{ Luas daun } & \multicolumn{2}{|c|}{ Indek luas daun } \\
\hline & 30 hst & 60 hst & 30 hst & 60 hst \\
\hline \multicolumn{5}{|c|}{ Naungan Plastik } \\
\hline W1 & $2,39 a$ & $6,671 b$ & $8,043 a$ & $5,558 \mathrm{a}$ \\
\hline W2 & $2,84 \mathrm{a}$ & 7,656 a & 8,168 a & 7,611 a \\
\hline W3 & $2,39 a$ & $6,728 b$ & $8,083 a$ & $5,817 \mathrm{a}$ \\
\hline \multicolumn{5}{|c|}{ Pupuk organik } \\
\hline N1 & $2,60 \mathrm{a}$ & $6.604 \mathrm{c}$ & $8,062 \mathrm{~b}$ & $5,802 \mathrm{c}$ \\
\hline N2 & $2,56 \mathrm{a}$ & $6.768 \mathrm{~b}$ & $7,993 \mathrm{~b}$ & $6,795 b$ \\
\hline N3 & $2,65 a$ & $6.873 b$ & $8,008 \mathrm{~b}$ & $7,926 a$ \\
\hline N4 & $2,35 \mathrm{a}$ & $7.828 \mathrm{a}$ & $8,367 a$ & $4,880 \mathrm{~d}$ \\
\hline \multicolumn{5}{|c|}{ Interaksi Pupuk organik dengan Naungan Plastik } \\
\hline W1N1 & $2,32 \mathrm{a}$ & $6,716 \mathrm{gh}$ & $7,926 a$ & $5,805 \mathrm{bc}$ \\
\hline W1N2 & $2,35 a$ & $6,593 \mathrm{i}$ & $8,258 \mathrm{a}$ & $5,450 \mathrm{bc}$ \\
\hline W1N3 & $2,56 a$ & $6,565 \mathrm{i}$ & $8,004 a$ & $6,336 \mathrm{bc}$ \\
\hline W1N4 & $2,32 \mathrm{a}$ & 6,811 e & $7,986 a$ & $4,639 \mathrm{c}$ \\
\hline W2N1 & $2,60 a$ & $6,881 d$ & $8,068 \mathrm{a}$ & $5,281 \mathrm{c}$ \\
\hline W2N2 & $2,75 a$ & $6,746 \mathrm{fg}$ & $7,792 a$ & $6,860 \mathrm{bc}$ \\
\hline W2N3 & $3,35 a$ & $7,104 b$ & $8,643 a$ & $12,431 \mathrm{a}$ \\
\hline W2N4 & $2,67 \mathrm{a}$ & 9,895 a & $8,168 a$ & $5,873 b c$ \\
\hline W3N1 & $2,89 a$ & $6,216 j$ & 7,918 a & $6,322 b c$ \\
\hline W3N2 & $2,58 a$ & $6,965 \mathrm{c}$ & 7,927 a & $7,805 b$ \\
\hline W3N3 & $2,04 \mathrm{a}$ & $6,951 \mathrm{c}$ & $8,455 a$ & $5,012 \mathrm{c}$ \\
\hline W3N4 & $2,06 \mathrm{a}$ & 6,780 ef & $8,033 a$ & $4,128 \mathrm{c}$ \\
\hline
\end{tabular}

Keterangan: angka-angka yang diikuti huruf yang sama pada kolom yang sama menunjukkan hasil yang tidak berbeda nyata berdasar uji DMRT pada taraf $\alpha=5 \%$ 
Tabel 2. Pengaruh pupuk organik, naungan plastik, dan interaksi pupuk organik dengan naungan terhadap laju pertumbuhan relatif, dan laju pertumbuhan tanaman pada tanaman bawang merah

\begin{tabular}{|c|c|c|}
\hline Perlakuan & Laju Pertumbuhan Tanaman & Laju pertumbuhan Relatif \\
\hline \multicolumn{3}{|c|}{ Naungan Plastik } \\
\hline W1 & $0,00176 \mathrm{c}$ & $0,072 \mathrm{a}$ \\
\hline W2 & $0,00199 \mathrm{~b}$ & $0,066 \mathrm{a}$ \\
\hline W3 & $0,00226 \mathrm{a}$ & $0,058 \mathrm{a}$ \\
\hline \multicolumn{3}{|c|}{ Pupuk organik } \\
\hline & $0,00183 c$ & $0.047 \mathrm{c}$ \\
\hline N1 & $0,00197 b$ & $0.056 \mathrm{~b}$ \\
\hline $\mathrm{N} 2$ & $0,00235 a$ & 0.106 a \\
\hline $\begin{array}{l}\text { N3 } \\
\text { N4 }\end{array}$ & $0,00188 b$ & $0.051 \mathrm{~b}$ \\
\hline \multicolumn{3}{|c|}{ Interaksi Pupuk organik dengan Naungan Plastik } \\
\hline W1N1 & $0,0018 \mathrm{a}$ & $0,048 \mathrm{a}$ \\
\hline W1N2 & $0,0020 \mathrm{a}$ & 0,059 a \\
\hline W1N3 & $0,0017 \mathrm{a}$ & $0,118 a$ \\
\hline W1N4 & $0,0016 a$ & $0,062 \mathrm{a}$ \\
\hline W2N1 & $0,0017 a$ & $0,056 \mathrm{a}$ \\
\hline W2N2 & $0,0019 a$ & $0,060 \mathrm{a}$ \\
\hline W2N3 & $0,0023 a$ & $0,101 \mathrm{a}$ \\
\hline W2N4 & 0,0020 a & 0,047 a \\
\hline W3N1 & $0,0019 a$ & 0,038 a \\
\hline W3N2 & 0,0021 a & $0,049 \mathrm{a}$ \\
\hline W3N3 & $0,0030 \mathrm{a}$ & $0,100 \mathrm{a}$ \\
\hline W3N4 & $0,0020 \mathrm{a}$ & 0,045 a \\
\hline
\end{tabular}

Keterangan: angka-angka yang diikuti huruf yang sama pada kolom yang sama menunjukkan hasil yang tidak berbeda nyata berdasar uji DMRT pada taraf $\alpha=5 \%$

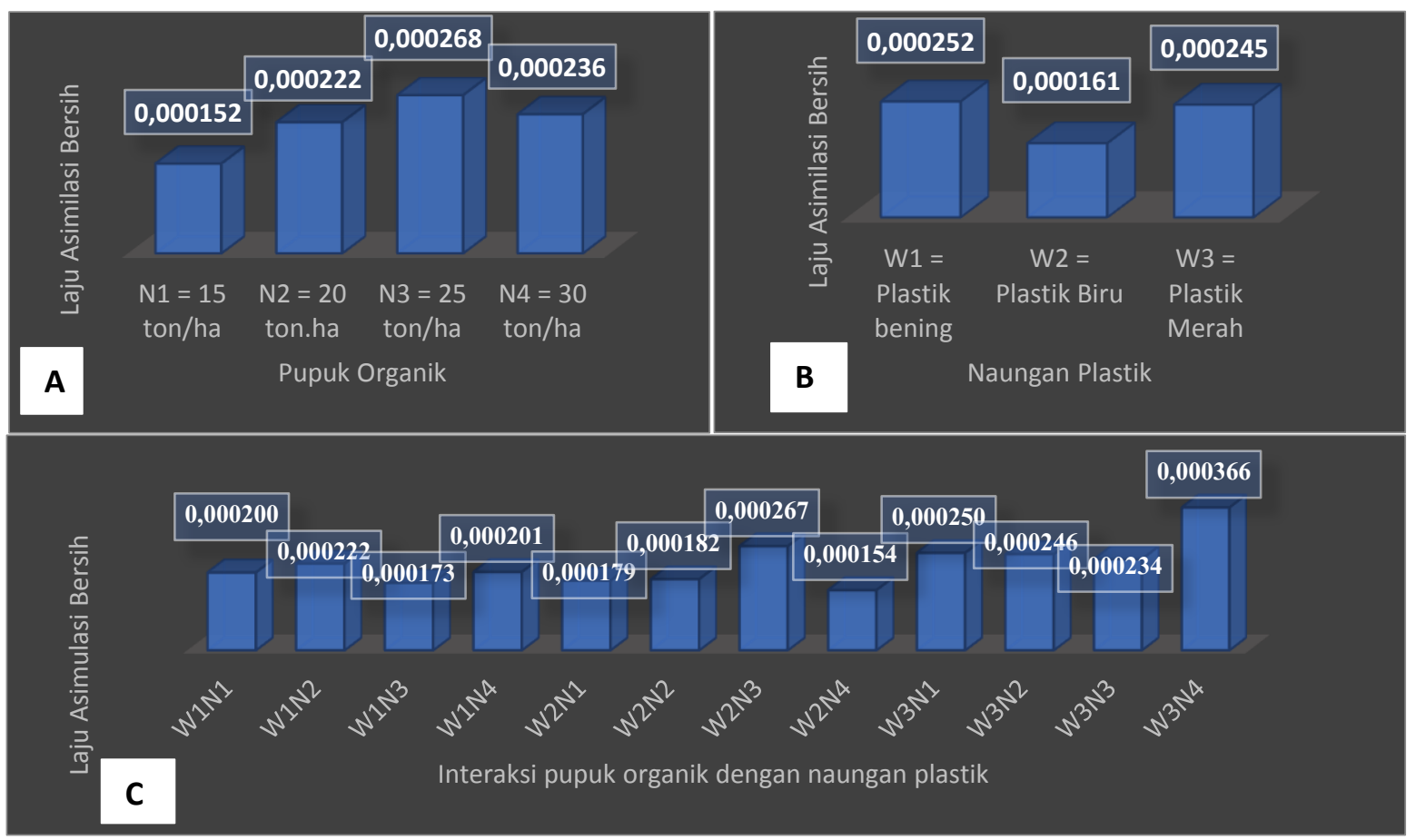

Gambar 1. (A): Pengaruh Pupuk Organik Terhadap Laju Asimilasi Bersih, (B): Pengaruh Naungan Plastik Terhadap Laju Asimilasi Bersih, dan (C): Pengaruh Interaksi antara Pupuk Organik dengan Naungan Plastik terhadap Laju Asimilasi Bersih 

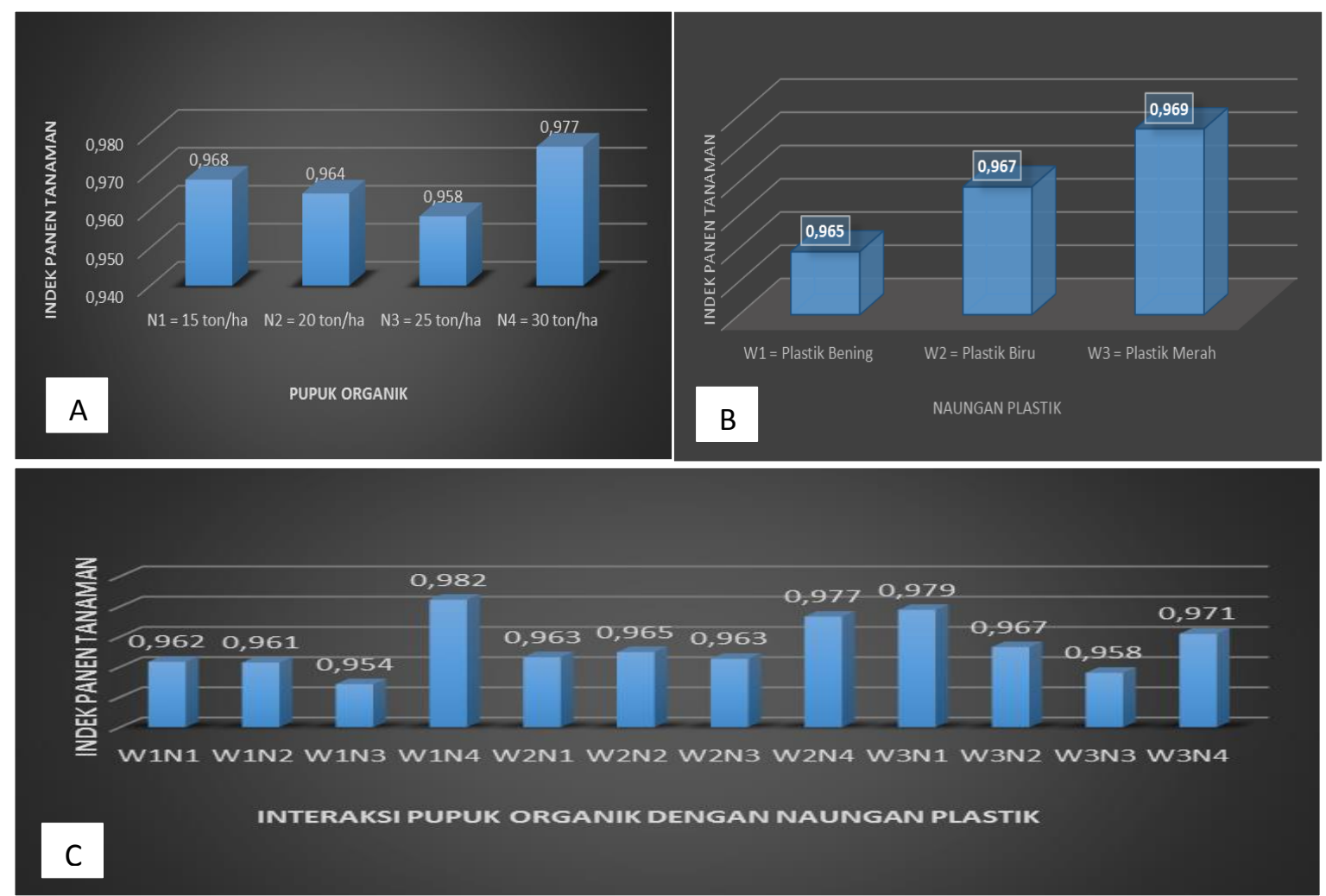

Gambar 2. (A) Pengaruh Pupuk Organik Terhadap Indek Panen Tanaman, (B) Pengaruh Naungan Plastik terhadap Indek Panen Tanaman, dan (C) Interaksi Pupuk Organik dengan Naungan Plastik terhadap Indek Panen Tanaman 